\begin{tabular}{|c|c|c|}
\hline ב & $\begin{array}{l}\text { International Journal of Current Research in } \\
\text { Biosciences and Plant Biology }\end{array}$ & $=$ \\
\hline & Volume 6 • Number 9 (September-2019) • ISSN: 2349-8o8o (Online) & \\
\hline $\begin{array}{l}\text { EXCELLENT } \\
\text { PUBLISHERS }\end{array}$ & Journal homepage: $\underline{w w w . i j c r b p . c o m}$ & \\
\hline
\end{tabular}

\title{
Adaptogenic effects of the leaves aqueous extract of Moringa oleifera in rats
}

\author{
Bonoy Lamou1, 2*, Ebal Minye Edmond², Mbouh Samuel², Hamadou André² \\ and Tan Vernyuy Paul1
}

\author{
${ }^{1}$ Department of Animal Biology and Physiology, Faculty of Science, University of Yaoundé I, \\ P.O. Box 812, Yaoundé, Cameroon \\ ${ }^{2}$ Department of Physical Activities Biology and Sport Education, National Institute of Youth and Sports, \\ P. O. Box 1016, Yaoundé, Cameroon \\ *Corresponding author; e-mail: lamoukessioo7@yahoo.com
}

\begin{tabular}{|c|c|}
\hline Arti & \\
\hline & \multirow{4}{*}{$\begin{array}{l}\text { The present study was undertaken to elucidate the mechanism responsible for the } \\
\text { adaptogenic effects of the leaves aqueous extract of Moringa oleifera in rats. Thirty two } \\
\text { male Wistar rats weighing } 154 \mathrm{~g} \text { were used. Four groups of rats ( } 8 \text { rats per group) were } \\
\text { fed a standard laboratory diet with or without the } M \text {. oleifera extract (o, 10o, 200 and } \\
400 \mathrm{mg} / \mathrm{kg} \text { body weight) for } 14 \text { days. The control group rats received distilled water. } \\
\text { Rats were allowed for swimming exercise, with a load (10\% of body weight) attached to } \\
\text { the tail, every alternate day for a period of } 14 \text { days and swimming time of each session } \\
\text { was recorded immediately. After the last training session, glyceaemia, lactatemia, } \\
\text { uraemia, triglyceridemia, hepatic and muscle glycogen, oxidative stress parameters } \\
\text { (superoxide dismutase, catalase, reduced glutathione, malondialdehyde) and } \\
\text { hematological parameters were measured. Results shown that extract of } M \text {. oleifera } \\
\text { ameliorated endurance capacity of rats by an increase in the swimming time, blood } \\
\text { hemoglobin, red blood cells, white blood cells, hepatic and muscle glycogen reserves } \\
\text { and the activity of antioxidant enzymes. Furthermore, the extract decreased blood } \\
\text { concentrations of malondialdehyde, lactate, triglycerides and urea. These results also } \\
\text { confirm that } 200 \mathrm{mg} / \mathrm{kg} \text { is the optimum dose with anti-fatigue activity. }\end{array}$} \\
\hline & \\
\hline Keywords & \\
\hline & \\
\hline
\end{tabular}

\section{Introduction}

Intense exercise can be sustained for only a few minutes before the force and motion generating capacity of skeletal muscle is severely compromised, a phenomenon which defines fatigue (You et al., 2011). Fatigue causes various disorders in relation to bio-regulatory, autonomic nervous, endocrine and immune system. The fatigue experienced by athletes in training and competition is a necessary part of the adaptive process (Ferrauti et al., 2003). The stressful components of training and competition may temporarily impair an athlete's performance (Barnett, 2006). This impairment may be transitory, lasting minutes or hours after training or competition, or lasting for a longer period, up to several days. Short-term impairment results from metabolic disturbances following high-intensity exercise (Westerblad et al., 2002). 
For several years, nutritional strategies such as overfeeding and ingesting carbohydrates/proteins before and after exercise have been the foundation for enhancing exercise performance and muscular strength (Yi, 2000). Many athletes use a variety of dietary supplements in the belief that a specific drug will have a positive influence on skill, strength, power, or endurance (Piattoly, 2005). Some dietitians and exercise scientists believe that an adequate diet which meets the recommended dietary allowance (RDA) for macronutrients, vitamins and minerals, is sufficient to achieve top performance. However, other experts believe that supplementation is necessary to restore specific nutrient, vitamin, or mineral levels that may be suppressed during prolonged or intense exercise.

Moringa oleifera ( $M$. oleifera) is a plant of Indian origin which is now widespread in Asia and Africa. It belongs to the Family Moringaceae with about 13 species (Foidl et al., 2001). It is commonly referred to as 'tree of life', 'miracle tree' or 'divine plant' due to its numerous nutritive, medicinal and industrial potentials (Fuglie, 2001). Different parts of this plant contain a profile of important minerals, and are a good source of proteins, vitamins, $\beta$-carotene, amino and various phenolic acids (Lamou et al., 2016). Various therapeutic potentials are also credited to different parts of the plant. It is reported to have antitumor, hepatoprotective, analgesic, antispasmodic, antipyretic, antiulcer, diuretic, hypotensive, hypolipidemic and antimicrobial activities. The leaves are widely consumed as a legume and used in traditional medicine in Africa in general and in Cameroon in particular. They are an excellent source of protein, metabolisable energy, vitamins (A, B, C, E), minerals, and contain the 10 amino acids essential to man (Lamou et al., 2016). M. oleifera leaves are used in traditional medicine to treat malnutrition, fever, headaches, nerve pain, diabetes and many other diseases (Mall and Tripathi, 2017).

Studies have revealed the widespread use of plant extracts in many African countries for performance enhancement (Tallec, 2008). It is therefore important to develop efficient and safe plant-based anti-fatigue products that can enhance exercise performance without deleterious effects on the health of the users. Recently it has been reported that aqueous leaves extract from $M$. oleifera had acute effect on physical fatigue (Lamou et al.,
2016). However, the chronic effects of this plant on endurance capacity have not been demonstrated. In the present study, we investigated adaptogenic effects by administrating the aqueous leaves extract of $M$. oleifera to rats and then subjecting the animals to exercises in the form of swimming. Glyceaemia, lactatemia, uraemia, triglyceridemia, hepatic and muscle glycogen, oxidative stress parameters (SOD, CAT, GPx and MDA), and hematological parameters were then measured.

\section{Materials and methods}

\section{Plant material and preparation of aqueous leaf extract of $M$. oleifera}

The fresh leaves of $M$. oleifera were harvested from the North Region of Cameroon in December 2014 and identified in the National Herbarium (Yaoundé) where a voucher specimen No. 49178/HNC exist. The leaves were cleaned immediately after harvest, cut into small pieces, and dried in the shade for about 2 weeks. The dried material was ground into a powder using an electrical homogenizer (Zaiba $\AA$ ). The aqueous extract was prepared as described by Thilza et al. (2010). $100 \mathrm{~g}$ of ground plant material was macerated in $1.5 \mathrm{l}$ of boiled distilled water for one hour. The mixture was filtered through Whatman filter paper No. 3 and the filtrate obtained was evaporated to dryness using a rotator evaporator at $45^{\circ} \mathrm{C}$. The extract obtained (22.9\% yield) was stored at $4^{\circ} \mathrm{C}$. Extract solution was prepared in distilled water each time prior to experimentation.

\section{Animals and grouping}

\section{Animals}

Male albino rats of Wistar strain weighing $154 \mathrm{~g}$ were obtained from the Animal house of the National Institute of Youth and Sports in Yaoundé. They were placed in plastic cages in a room under standard laboratory conditions (temperature 20 to $30^{\circ} \mathrm{C}$, relative air humidity 45 to $55 \%$, and $12 / 12 \mathrm{~h}$ light/dark cycle). The rats were fed with a basal diet and water ad libitum. The feed was a standard rat chow (National Veterinary Laboratory (LANAVET), Cameroon) composed of carbohydrates (52\%), protein (22\%), fat (6.5\%), water (12\%), ash (6\%), and fiber (4.5\%). The authorization for the use of laboratory animals in 
this study was obtained from the Cameroun National Ethics committee (Reg. No FWAIRBo0001954). The use, handling and care of animals were done in adherence to the European Convention (Strasbourg, 18.III.1986) for the protection of vertebrate animals used for experimental and other purposes (ETS-123), with particular attention to Part III, articles 7, 8 and 9. The animals were transferred to the laboratory at least 1 hour before the start of the experiment. The experiments were performed during the day (11:00-17:0o h).

\section{Animal grouping}

After two weeks of acclimatization, thirty two rats were divided randomly into four groups of eight rats each: group 1: a control group which received the vehicle (distilled water) only, and three treatment groups (group 2, 3 and 4) which received 100,200 and $400 \mathrm{mg} / \mathrm{kg}$, respectively, of $M$. oleifera extract orally once a day for 14 days. The quantity of food and water consumed by each group of rats, as well as body weights were measured every two days during 14 days, between 11:00 $\mathrm{AM}$ and 12:00 AM before extract administration.

\section{Weight loaded force swimming Test}

The weight loaded force swimming test was performed as describe previously (Qi et al., 2014) but with some modifications. The rats of the extract-treated and control groups were allowed for swimming exercise every alternate day for a period of 14 days. Each animal was supplied with a constant load (corresponding to $10 \%$ of the body weight) tagged to the tail, and placed individually in a swimming pool $(90 \mathrm{~cm} \times 45 \mathrm{~cm} \times 45 \mathrm{~cm})$, filled with water to a depth of $35 \mathrm{~cm}$ and maintained at $25 \pm 1^{\circ} \mathrm{C}$. Exhaustion was determined by observing loss of coordinated movements and failure to return to the surface within $10 \mathrm{sec}$ and swimming time was recorded immediately. The rats were then removed from the pool, dried with a paper towel, and returned to their original cages. The pool water was replaced after each session. After the last training session, the rats were rested for an hour and then sacrificed (under ether anesthesia) by cutting through the jugular vein. Blood samples were taken into sterile tubes and serum prepared (centrifuging at $3000 \mathrm{rpm}$ for $10 \mathrm{~min}$ ) for the analysis of blood glucose (Glu), triglycerides concentration (TG), blood lactic acid (BLA) and blood urea nitrogen (BUN). Another part of blood collected into bottles containing EDTA as anticoagulant was used to determine blood cell count. Vital body organs (spleen, fatty mass, heart, lungs, brain, kidneys and testicles) were cleaned using $0.9 \%$ saline and then weighed using a sensitive electronic balance. Tissue samples of liver and gastrocnemius muscle were taken and stored frozen at $-20^{\circ} \mathrm{C}$ awaiting determination of glycogen and antioxidant status parameters.

\section{Measurement of serum biochemical parameters and blood cell count}

Blood cell count in all rat groups was measured using a blood analyzer (Hospitex Diagnostic Hema Screen 18). The serum levels of glucose were estimated using a glucometer (Reader AccuCHEK $囚$ Active). Blood lactic acid concentrations and levels of BUN were measured using an Llactate assay kit (Abcam 65331 L-Lactate assay kit) and a colorimetric and enzymatic method (Bioassay System, CA Kit), respectively. Triglyceride concentrations were measured using a commercial kit for measurement of triglycerides in serum or plasma (Enzymatic Trinder Method).

\section{Measurement of tissue glycogen}

Liver and muscle glycogen contents were measured calorimetrically using anthrone reagent (Chun and Yin, 1998). Briefly, after hydrolysis of the liver and gastrocnemius muscle samples in $30 \% \mathrm{KOH}$ at $100^{\circ} \mathrm{C}$ for $30 \mathrm{~min}, 1.5 \mathrm{ml}$ of anhydrous ethanol was added to the vials. After centrifugation at $4000 \times \mathrm{g}$ for $15 \mathrm{~min}$, the supernatants were discarded. 0.5 $\mathrm{ml}$ of distilled water and $1 \mathrm{ml}$ of $0.2 \%$ anthrone were added, and the vials were placed in a boiling water bath for $20 \mathrm{~min}$. The absorbance of the solution in vials was determined at $620 \mathrm{~nm}$ using a spectrophotometer (V-530, Jasco Co., Japan).

\section{Measurement of antioxidant status in liver and gastrocnemius muscle}

The liver and gastrocnemius muscle tissue (1g of each) were homogenized in $4 \mathrm{ml}$ of Tris/ $\mathrm{HCl}$. The tissue homogenates were centrifuged at $4000 \mathrm{~g}$ for $15 \mathrm{~min}$ at $4^{\circ} \mathrm{C}$ and the supernatants were assessed for the antioxidant status. Lipid peroxidation (the 
level of thiobarbituric acid reactive substances in terms of Malondialdehyde (MDA)) was measured as described previously (Wilbur et al., 1949), and total glutathione (GPx) content was measured according to the method of Ellman (1959). Catalase (CAT) activity was measured according to the method of Sinha (1972). Superoxide dismutase (SOD) activity was measured using the pyrogallol autoxidation method (Misra and Fridovich, 1972).

\section{Statistical analysis}

Statistical analysis was done by one-way analysis of variance (ANOVA) followed by the Dunnett's test for multiple comparisons and $P$ values less than 0.05 were considered as significant. The results are expressed as mean \pm standard error of mean (SEM).

\section{Results}

\section{Body weight, swimming time, food and water intake}

Administration of $M$. oleifera extract did not bring about significant differences in food intake $(\mathrm{P}>$ o.05). Significant difference in water intake was observed at the $200 \mathrm{mg} / \mathrm{kg}$ dose (Table 1). The swimming exercise with $10 \%$ tail load was carried out for 14 days to evaluate swimming endurance capacity of rats. On day one, no significant difference in swimming time between control and extract-treated groups was observed ( $>>0.05)$. However, it was observed that the swimming time was significantly increased from day 4 to the last day (day 14). Maximum swimming time was recorded on day 14 with the $200 \mathrm{mg} / \mathrm{kg}$ dose (587.50 \pm 51.64 seconds) compared with the control group (217.75 \pm 46.64 seconds) $(\mathrm{P}<0.05)$ (Fig. 1). We did not observe significant differences in final body weights (173-192g) (Fig. 2) following 14 days of the training program and administration of extract. Body weight gain ranged between 18.75 and $38.00 \mathrm{~g}$ for the four treatment groups.

\section{Relative organ weights and antioxidant status in liver and muscle}

As shown in Table 2, Moringa extract (100 and $200 \mathrm{mg} / \mathrm{kg}$, respectively) significantly increased relative heart weights $(0.38 \pm 0.03$ and $0.42 \pm 0.10 \%)$ and brain weights (0.91 \pm 0.14 and $0.99 \pm 0.19 \%)$ compared with the control group
$(0.29 \pm 0.04 \quad$ and $\quad 0.70 \pm 0.07 \%) \quad(\mathrm{P}<0.05)$. Antioxidant Status in Liver and Muscle are presented in Table 3, MDA concentrations in liver and gastrocnemius muscle of rats treated with Moringa extract were significantly lower $(\mathrm{P}<0.05)$ compared with the controls. However, the activity of SOD, GPx and CAT in liver and gastrocnemius muscle of control rats were significantly higher ( $P$ $<0.05$ ) compared with the extract-treated groups.

\section{Hematological parameters}

Hematological parameters of the rats measured post exercise are presented in Table 4. There were significant increases $(\mathrm{P}<0.05)$ in hemoglobin $(\mathrm{Hb})$, percentage of Lymphocyte (\% LYM), White Blood Cell (WBC), and Red Blood Cell (RBC) in rats given $200 \mathrm{mg} / \mathrm{kg}$ and $400 \mathrm{mg} / \mathrm{kg}$ of extract compared with the controls. On the contrary, the extract decreased percentage of Granulocyte (\% GRA) in rats given $200 \mathrm{mg} / \mathrm{kg}$ of extract compared with the controls $(\mathrm{P}<0.05)$.

\section{Serum biochemical parameters}

Serum biochemical parameters are shown in Table 5. Results show that after the last swimming exercise, blood glucose levels were not significantly higher $(\mathrm{P}>0.01)$ in the extract-treated groups compared with the controls. Blood lactate levels were significantly $(\mathrm{P}<0.001)$ reduced by extract treatment (38.55-53.83\%) compared with the controls. In the same way, BUN concentrations of extract-treated rats $(22.99-29.06 \mathrm{mg} / \mathrm{dl})$ were significantly and dose-dependently lower $(\mathrm{P}<0.05)$ following the experimental swimming exercise compared with controls $(35.75 \mathrm{mg} / \mathrm{dl})$. Moringa extract-treated group had also, significantly lower TG levels (Table 5), which were 58-62\% lower than those of control group $(\mathrm{P}<0.01-\mathrm{P}<0.001)$.

\section{Muscle and hepatic glycogen}

Following the swimming exercise, extract-treated rats at all dose levels maintained significantly higher concentrations of muscle and hepatic glycogen compared with the controls $(\mathrm{P}<0.05)$ (Table 6). Maximum value of liver $(42.09 \pm 7.61$ $\mathrm{mg} / \mathrm{g})$ and muscle $(5.05 \pm 1.28 \mathrm{mg} / \mathrm{g})$ glycogen were recorded in the $200 \mathrm{mg} / \mathrm{kg}$ group compared with the controls, $(23.89 \pm 4.34 \mathrm{mg} / \mathrm{g}$ and $2.06 \pm 0.77$ $\mathrm{mg} / \mathrm{g}$ for liver and muscle glycogen respectively). 
Table 1. Effect of $M$. oleifera extract on food (g/group/week) and water (ml/group/week) intake in rats.

\begin{tabular}{|c|c|c|c|c|}
\hline Food intake & Control & $\begin{array}{l}\text { M. oleifera } \\
\text { (100 } \mathrm{mg} / \mathrm{kg})\end{array}$ & $\begin{array}{l}\text { M. oleifera } \\
\text { (200 } \mathrm{mg} / \mathrm{kg})\end{array}$ & $\begin{array}{l}\text { M. oleifera } \\
(400 \mathrm{mg} / \mathrm{kg})\end{array}$ \\
\hline Week 1 & $343.00 \pm 60.85$ & $333.33 \pm 22.81$ & $315.67 \pm 59.09$ & $333.33 \pm 44.74$ \\
\hline Week 2 & $275.75 \pm 68.95$ & $287.00 \pm 48.15$ & $294.50 \pm 45.76$ & $279.75 \pm 69.27$ \\
\hline \multicolumn{5}{|l|}{ Water intake } \\
\hline Week 1 & $241.67 \pm 5.86$ & $251.33 \pm 6.03$ & $279.67 \pm 13.58 *$ & $255 \cdot 33 \pm 25.01$ \\
\hline Week 2 & $240.50 \pm 9.15$ & $254.75 \pm 15.59$ & $265.25 \pm 9.50^{*}$ & $243.50 \pm 9.29$ \\
\hline
\end{tabular}

Each value represents the mean \pm SEM, $n=8 .{ }^{*} P<0.05$ compared with control group.

Table 2. Effect of $M$. oleifera extract on relative organ weights of the rats.

\begin{tabular}{lllll}
\hline Organs (g) & Control & $\begin{array}{l}\text { M. oleifera } \\
(\mathbf{1 0 0 ~} \mathbf{~ m g} / \mathbf{k g})\end{array}$ & $\begin{array}{l}\text { M. oleifera } \\
(\mathbf{2 0 0} \mathbf{~ m g} / \mathbf{k g})\end{array}$ & $\begin{array}{l}\text { M. oleifera } \\
(\mathbf{4 0 0} \mathbf{~ m g} / \mathbf{k g})\end{array}$ \\
\hline Liver & $3.29 \pm 0.45$ & $3.31 \pm 0.25$ & $3.36 \pm 0.42$ & $3.12 \pm 0.42$ \\
Lungs & $0.79 \pm 0.22$ & $0.89 \pm 0.25$ & $1.11 \pm 0.32$ & $0.83 \pm 0.23$ \\
Left kidney & $0.29 \pm 0.06$ & $0.31 \pm 0.05$ & $0.35 \pm 0.11$ & $0.29 \pm 0.07$ \\
Right kidney & $0.28 \pm 0.05$ & $0.32 \pm 0.04$ & $0.33 \pm 0.03$ & $0.32 \pm 0.06$ \\
Left testis & $0.57 \pm 0.08$ & $0.61 \pm 0.07$ & $0.68 \pm 0.10$ & $0.62 \pm 0.09$ \\
Right testis & $0.58 \pm 0.11$ & $0.63 \pm 0.06$ & $0.67 \pm 0.10$ & $0.62 \pm 0.12$ \\
Heart & $0.29 \pm 0.04$ & $\mathbf{0 . 3 8} \pm \mathbf{0 . 0 3}$ & $\mathbf{0 . 4 2} \pm \mathbf{0 . 1 0}$ & $0.35 \pm 0.06$ \\
Spleen & $0.24 \pm 0.11$ & $0.30 \pm 0.11$ & $0.34 \pm 0.14$ & $0.31 \pm 0.08$ \\
Brain & $0.70 \pm 0.07$ & $\mathbf{0 . 9 1} \pm \mathbf{0 . 1 4}$ & $\mathbf{0 . 9 9} \pm \mathbf{0 . 1 9}$ & $0.76 \pm 0.09$ \\
Fatty mass & $1.01 \pm 0.20$ & $\mathbf{1 . 0 2} \pm 0.21$ & $1.18 \pm 0.28$ & $1.06 \pm 0.22$ \\
\hline
\end{tabular}

Each value represents the mean \pm SEM, $n=8 .{ }^{*} P<0.05,{ }^{* *} P<0.01$, and ${ }^{* * *} P<0.001$ compared with control group.

Table 3. Effect of $M$. oleifera extract on rat hepatic and muscle antioxidant parameters.

\begin{tabular}{|c|c|c|c|c|}
\hline Parameters & Control & $\begin{array}{l}\text { M. oleifera } \\
(100 \mathrm{mg} / \mathrm{kg})\end{array}$ & $\begin{array}{l}\text { M. oleifera } \\
(200 \mathrm{mg} / \mathrm{kg})\end{array}$ & $\begin{array}{l}\text { M. oleifera } \\
(400 \mathrm{mg} / \mathrm{kg})\end{array}$ \\
\hline \multicolumn{5}{|l|}{ Hepatic parameters } \\
\hline SOD (U/mg protein) & $29.90 \pm 2.65$ & $33.05 \pm 2.51$ & $33.84 \pm 3.52^{*}$ & $34 \cdot 10 \pm 3 \cdot 71^{*}$ \\
\hline MDA $(\mu \mathrm{mol} / \mathrm{g})$ & $47.00 \pm 7.76$ & $39.13 \pm 5.55$ & $33.80 \pm 7.58^{* *}$ & $33.60 \pm 6.17^{* *}$ \\
\hline CAT (U/mg protein) & $21.40 \pm 2.43$ & $23.89 \pm 1.71$ & $25.53 \pm 1.87^{* *}$ & $24.63 \pm 2.71^{*}$ \\
\hline GPx $(\mu \mathrm{mol} / \mathrm{mg}$ of protein $)$ & $2.40 \pm 0.50$ & $4.35 \pm 1.06^{* *}$ & $4.82 \pm 1.55^{* * *}$ & $5.69 \pm 0.62^{* * *}$ \\
\hline \multicolumn{5}{|l|}{ Muscle parameters } \\
\hline $\mathrm{SOD}$ (U/mg protein) & $5.85 \pm 0.89$ & $7.25 \pm 0.86^{*}$ & $7.60 \pm 1.23^{* *}$ & $7.42 \pm 0.95^{*}$ \\
\hline $\operatorname{MDA}(\mu \mathrm{mol} / \mathrm{g})$ & $30.08 \pm 5.05$ & $22.34 \pm 3.21^{* *}$ & $18.92 \pm 3.52^{* * *}$ & $22.03 \pm 4.47^{* *}$ \\
\hline CAT (U/mg protein) & $0.25 \pm 0.03$ & $0.29 \pm 0.02 *$ & $0.30 \pm 0.02^{* *}$ & $0.29 \pm 0.03^{* *}$ \\
\hline GPx ( $\mu \mathrm{mol} / \mathrm{mg}$ of protein $)$ & $0.82 \pm 0.40$ & $2.90 \pm 1.17^{* *}$ & $2.39 \pm 1.65^{*}$ & $3.71 \pm 0.87^{* * *}$ \\
\hline
\end{tabular}

Each value represents the mean \pm SEM, $n=8$. ${ }^{*} P<0.05,{ }^{* *} P<0.01$, and ${ }^{* * *} P<0.001$ compared with control group.

Table 4. Effect of M. oleifera aqueous extract on hematological parameters.

\begin{tabular}{|c|c|c|c|c|}
\hline Parameter & Control & $\begin{array}{l}\text { M. oleifera } \\
(100 \mathrm{mg} / \mathrm{kg})\end{array}$ & $\begin{array}{l}\text { M. oleifera } \\
(200 \mathrm{mg} / \mathrm{kg})\end{array}$ & $\begin{array}{l}\text { M. oleifera } \\
(400 \mathrm{mg} / \mathrm{kg})\end{array}$ \\
\hline $\mathrm{WBC} \times 10^{3} / \mathrm{mm}^{3}$ & $7.04 \pm 1.73$ & $7.70 \pm 2.02$ & $9.94 \pm 0.92^{* *}$ & $9.72 \pm 1.34^{* *}$ \\
\hline $\mathrm{LYM} \times 1 \mathrm{O}^{3} / \mathrm{mm}^{3}$ & $1.76 \pm 0.60$ & $2.46 \pm 0.96$ & $4.42 \pm 1.21^{* * *}$ & $3.88 \pm 1.16$ *** \\
\hline $\mathrm{MON} \times 1 \mathrm{O}^{3} / \mathrm{mm}^{3}$ & $0.88 \pm 0.22$ & $0.87 \pm 0.23$ & $0.90 \pm 0.22$ & $0.94 \pm 0.30$ \\
\hline $\mathrm{GRA} \times 10^{3} / \mathrm{mm}^{3}$ & $4.40 \pm 1.47$ & $4.37 \pm 1.31$ & $4.71 \pm 1.47$ & $5.03 \pm 0.76$ \\
\hline \%LYM (\%) & $25 \cdot 34 \pm 7.42$ & $31.36 \pm 8.53$ & $45.03 \pm 13.90^{* * *}$ & 39.19 $\pm 7.20 *$ \\
\hline$\% \mathrm{MON}(\%)$ & $13.20 \pm 5.38$ & $11.60 \pm 2.68$ & $9.13 \pm 2.33$ & $9.85 \pm 3.46$ \\
\hline \%GRA (\%) & $61.46 \pm 6.91$ & $57.03 \pm 7.97$ & $46.75 \pm 12.25^{* *}$ & $52.14 \pm 8.07$ \\
\hline $\mathrm{RBC} \times 10^{6} / \mathrm{mm}^{3}$ & $5.30 \pm 0.77$ & $5.63 \pm 0.55$ & $6.63 \pm 0.91^{* *}$ & $6.25 \pm 0.81$ \\
\hline НСТ (\%) & $34.39 \pm 2.44$ & $37 \cdot 31 \pm 2.15$ & $38.59 \pm 4.39$ & $39.23 \pm 5.71$ \\
\hline $\mathrm{Hb}(\mathrm{g} / \mathrm{dl})$ & $12.04 \pm 1.08$ & $13.06 \pm 0.81$ & $13.54 \pm 0.82 *$ & $13.05 \pm 1.08$ \\
\hline $\mathrm{PLA} \times 10^{3} / \mathrm{mm}^{3}$ & $539.37 \pm 90.95$ & $622.25 \pm 110.67$ & $628.50 \pm 169.27$ & $654.62 \pm 91.39$ \\
\hline
\end{tabular}


Table 5. Effect of M. oleifera extract on rat hepatic and muscle glycogen.

\begin{tabular}{lll}
\hline \multirow{2}{*}{ Groups } & Glycogen content (mg/g) & \\
\cline { 2 - 3 } Control & Liver & Muscle \\
M. oleifera $(100 \mathrm{mg} / \mathrm{kg})$ & $23.89 \pm 4.34$ & $2.06 \pm 0.77$ \\
M. oleifera $(200 \mathrm{mg} / \mathrm{kg})$ & $30.35 \pm 4.44$ & $\mathbf{3 . 7 7}^{* 1.33}$ \\
M. oleifera $(400 \mathrm{mg} / \mathrm{kg})$ & $\mathbf{4 2 . 0 9}^{*}+\mathbf{1 6}^{* * *}$ & $\mathbf{5 . 0 5}^{ \pm 1.28}$ \\
\hline
\end{tabular}

Each value represents the mean \pm SEM, $n=8$. ${ }^{*} P<0.05$ and ${ }^{* * *} P<0.001$ compared with control group.

Table 6. Effect of $M$. oleifera extract on rat serum biochemical parameters.

\begin{tabular}{|c|c|c|c|c|}
\hline Parameters & Control & $\begin{array}{l}\text { M. oleifera } \\
(100 \mathrm{mg} / \mathrm{kg})\end{array}$ & $\begin{array}{l}\text { M. oleifera } \\
(200 \mathrm{mg} / \mathrm{kg})\end{array}$ & $\begin{array}{l}\text { M. oleifera } \\
(400 \mathrm{mg} / \mathrm{kg})\end{array}$ \\
\hline (mg/dl) & 157.12 & $170.25 \pm 29.35$ & $132.37 \pm 35.42$ & $157.62 \pm 26.75$ \\
\hline Lactatemia $(\mathrm{mmol} / \mathrm{L})$ & $26.25 \pm 1.91$ & $15.50 \pm 1.77^{* * *}$ & $12.12 \pm 1.13 * * *$ & $16.13 \pm 1.46^{* * *}$ \\
\hline Urea (mg/dl) & $35.75 \pm 6.90$ & $29.06 \pm 5.63$ & $23.47 \pm 5.04^{* *}$ & $22.99 \pm 6.84^{* * *}$ \\
\hline Triglycerides $(\mathrm{mg} / \mathrm{dl})$ & $157.29 \pm 25.57$ & $61.24 \pm 7.42^{* * *}$ & $59.65 \pm 9.72^{* * *}$ & $64.44 \pm 10.46^{* * *}$ \\
\hline
\end{tabular}

Each value represents the mean \pm SEM, $n=8 .{ }^{* *} P<0.01$, and ${ }^{* * *} P<0.001$ compared with control group.

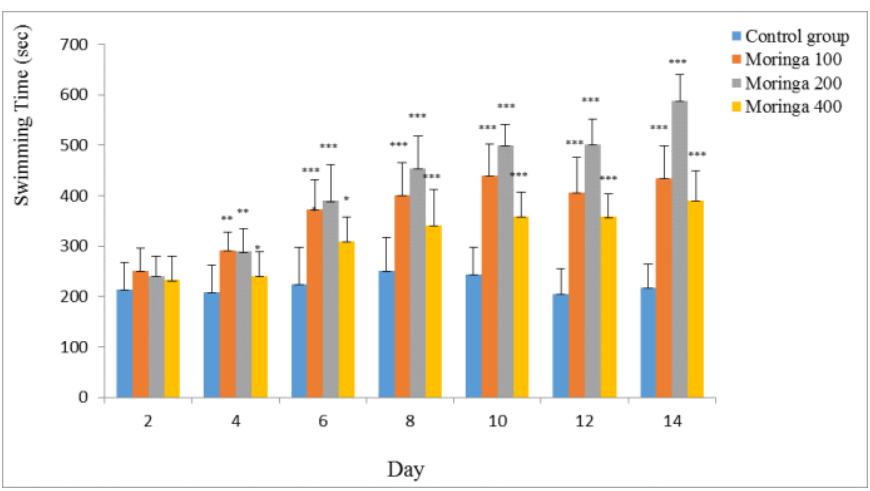

Fig. 1: Effect of the $M$. oleifera aqueous extract on swimming time in rats. Data are presented as Mean \pm SEM, $\mathrm{n}=8 .{ }^{*} P<0.05,{ }^{* *} P<0.01$, and ${ }^{* * *} P<0.001$ compared with control group. Control group $=$ rats treated with distilled water; Moringa 100, Moringa 200 and Moringa 400 group= rats treated with 100, 200 and $400 \mathrm{mg} / \mathrm{kg}$ of $M$. oleifera extract, respectively.

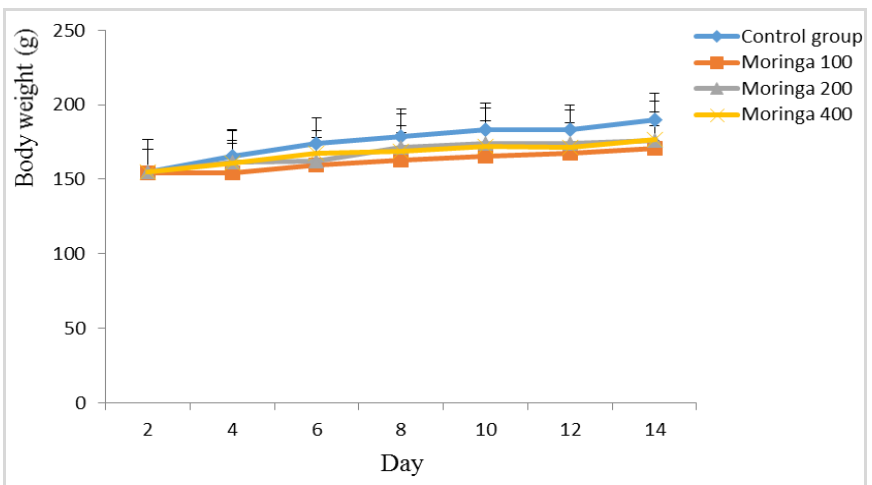

Fig. 2: Body weight change of the rats during the experimentation. The value are expressed as Mean \pm SEM, $n=16$. Control Group $=$ rats treated with distilled water; Moringa100, Moringa 200 and Moringa 400 group $=$ rats treated with 100,200 and $400 \mathrm{mg} / \mathrm{kg}$, respectively, of $M$. oleifera extract.

\section{Discussion}

The present study explored the potential of leaves aqueous extract from $M$. oleifera to enhance physical endurance by facilitating recovery from fatigue and preventing various types of damages from exercise stress (adaptations). The weightforced swimming test used in this work represents a valid animal model for screening anti-fatigue potency of various bioactive compounds (Hao et al., 2014). The data on swimming exercise showed that administration of Moringa extract extended the swimming time significantly (67.71 to $45.17 \%$ of amelioration from the first to the last session) and had no significant effect on body weight. Similar results have been reported by Prasad and Khanum (2012), on the anti-fatigue activity of the ethanolic extract of Ocimum sanctum in rats subjected to weight forced swimming test every alternate day for two weeks. In the present study, swimming exercise significantly increased relative heart and brain weights $(\mathrm{P}<0.05)$. Diet has a significant effect on brain and cardiovascular function (Mattson, 2000). Increase in relative organ weight (heart and brain) of rats during training session, resulting from administration of Moringa extract may indicate the improvement in the nutritional state of the animal. Moringa leaves have a long history as an herbal remedy, and nutritious addition to the diet (Mall and Tripathi, 2017). Moringa leaves are an excellent source of protein, and are rich in metabolisable energy, vitamins, minerals, fats, and contain the 10 amino acids essential to man (Oyeyinka and Oyeyinka, 2018). 
Regular exercise training induces the endogenous anti-oxidative system and protects the body against adverse effects of oxidative damage (Belviranli and Gökbel, 2006). Regular exercise has been shown to increase the activity of antioxidant enzymes. Evaluation of the long-term effects of exercise training showed that muscle content of reduced glutathione (GSH), a main substrate for GPx, increased and the glutathione disulfide ratio decreased during exercise training (Elokda and Nielsen, 2007). Endurance training also has been accompanied with higher activity of CAT and SOD (Terblanche, 2000). On the contrary, exercise training has been shown to decrease lipid peroxidation (MDA) in liver and muscle tissues (Alessio and Goldfarb, 1988). In addition, activity of antioxidant enzymes may lead to muscle hypertrophy, better cardiac function, lower resting heart rate, improved glucose uptake, and better endurance (Davies et al., 1986). This adaptation is effectively influenced by physiological and environmental factors such as gender, age, and diet (Shao, 2011). As shown in Table 3, MDA concentrations in liver and gastrocnemius muscle of rats treated with Moringa extract were significantly lower $(\mathrm{P}<0.05)$ compared with the controls, while the activity of SOD, GPx and CAT in liver and gastrocnemius muscle of control rats were significantly hither (P $<0.05)$ compared with the extract-treated groups. These results can be explained by the fact that, apart from the endogenous antioxidants, which are obviously regulated by exercise, exogenous antioxidants such as vitamin $\mathrm{C}, \mathrm{E}$, and carotenoids contained in Moringa leaves extract can be beneficial during exercise. These results are in accordance with the findings by Wang and Yan (2010), which demonstrated similar effects of ginseng polysaccharides on MDA and GPx levels. They also confirm earlier findings by Lamou et al. (2016) on antioxidant and anti-fatigue effects of Moringa extract in rats submitted to an acute exercise.

Hematological parameters of the rats measured post exercise are presented in Table 4 . There were significant increases $(\mathrm{P}<0.05)$ in $\mathrm{Hb}$ (Moringa 200), \%LYM, WBC, and RBC in rats given 200 $\mathrm{mg} / \mathrm{kg}$ and $400 \mathrm{mg} / \mathrm{kg}$ of extract compared with the controls. $\mathrm{Hb}$ is the main component of erythrocytes whose main function is to serve as the carrier for oxygen and carbon dioxide. $\mathrm{Hb}$ also plays a role in the maintenance of the body fluid's acid/alkali balance (Nikinmaa, 1997). Therefore, it can directly affect energy metabolism, body function and exercise ability, the loading capacity of the exercise and consequently fatigue. $\mathrm{Hb}$ normally is one of the indicators that reflect the degree of recovery from fatigue after exercise, and higher levels of $\mathrm{Hb}$ can improve exercise ability. Our results are in accordance with the findings by Okwari et al. (2014), who demonstrated similar effects of the leaf aqueous extract of $M$. oleifera on hemoglobin levels in rats subjected to thermooxidized palm oil diet-induced toxicity.

Table 4 also shows that extract treatment increased significantly \%LYM, WBC, and RBC in rats given $200 \mathrm{mg} / \mathrm{kg}$ and $400 \mathrm{mg} / \mathrm{kg}$ of extract compared with the controls $(\mathrm{P}<0.05)$. In contrary, Moringa extract decreased \%GRA in rats given $200 \mathrm{mg} / \mathrm{kg}$ of extract compared with the controls $(\mathrm{P}<0.05)$. Many studies describe changes induced by physical exercise on sub-types of blood mononuclear cells (Peake and Suzuki, 2004). In fact, strenuous exercise can elicit muscle injuries, which then lead to the activation of the neutrophils and macrophages via interferon- ${ }_{\Upsilon}\left(\mathrm{IFN}_{\Upsilon}\right)$, interleukin1 (IL-1) and tumor necrosis factor (TNF) (Moylan and Reid, 2007). These immune cells excessively produce ROS (oxidative burst), which is a central component of neutrophil defense mechanism. Thus, a single bout of exhaustive exercise has been shown to cause oxidative damage in untrained persons while in trained subjects, no such effects are observed due to an increased resistance of such persons to oxidative stress (Wang et al., 2006).

Muscular work, performed aerobically in the postabsorptive state, depends mainly on the energy provided by utilization of TG or fatty acids. It is documented that during prolonged exercises the body increases clearance of plasma TG by skeletal muscle to provide sufficient energy consumption (Jones and Havel, 1967). A lot of folk medicines and functional foods were certified to increase clearance of plasma TG, and thus, make better utilization of fat during swimming (Jung et al., 2004). Another possible explanation for the antifatigue effect seen following Moringa extract treatment could involve TG mobilization during exercise, as indicated by the decrease in TG level. Such an effect might become advantageous during prolonged exercise, since better utilization of TG 
allows the sparing of glycogen and therefore delays fatigue (Wu et al., 2007). Our results showed that Moringa extract group has significantly lower TG content (Table 5), which is 58.29-62.08 \% lower than that of control group $(\mathrm{P}<0.01-\mathrm{P}<0.001)$. This suggests that Moringa extract increased fat mobilization in trained rats.

Serum biochemical parameters are shown in Table 5. Results show that blood lactate levels were significantly $(\mathrm{P}<0.001)$ reduced $(38.55-53.83 \%)$ by extract treatment compared with the controls (Table 5). It has been reported that strenuous exercise alters the levels of blood parameters particularly causing an increased accumulation of lactate, a biomarker for fatigue, in the muscle and plasma compared to resting conditions (Tan et al., 2012). Lactate is a catabolic product of glycolysis and therefore can be used as an index of anaerobic metabolism. The accumulation of lactate eventually leads to the occurrence of fatigue and exhaustion in the exercising subject (Jung et al., 2004). Anti-fatigue agents have been shown to effectively work by delaying lactate accumulation either by reducing the glycolytic process or by removing the blood lactate (Li et al., 2008). The leaf extract of $M$. oleifera could effectively delay the onset of fatigue through one or both of these mechanisms.

Blood urea nitrogen (BUN), the product of protein and amino acid metabolism, is a sensitive index for evaluating the bearing capability when human bodies suffer from a physical load (Huang et al., 2011). Thus, the more the body is adapted for exercise tolerance, the more significantly the BUN level decreases (Tsopanakis and Tsopanakis, 1998). Reduced BUN levels also reflect the reduction in protein metabolism, indicative of enhanced endurance. BUN levels are shown in Table 5. BUN concentrations of extract-treated rats (22.99-29.06 mg/dl) were significantly and dosedependently lower $(\mathrm{P}<0.05)$ following the experimental swimming exercise compared with controls $(35.75 \mathrm{mg} / \mathrm{dl})$. The results suggested that treatment with $M$. oleifera extract could decrease the level of BUN of rats after swimming exercise, which indicated that they could reduce hepatic amino acid and protein catabolism during exercise and ameliorate recovery.

Following the swimming exercise, extract-treated rats at all dose levels maintained significantly higher concentrations of muscle and hepatic glycogen compared with the controls (Table 6). Energy for exercise is initially derived from the breakdown of glycogen and later from circulating glucose released by the liver (Suh et al., 2007). The contribution of glycogen to energy production during exhaustive exercise is necessary because glycogen can be degraded rapidly to produce adenosine triphosphate both aerobically and anaerobically (Andreeva et al., 2001). Fatigue sets in when most of the glycogen is already consumed. Thus, liver and muscle glycogen are sensitive parameters related to fatigue (Ding et al., 2011). Enhancement of exercise capacity could be accounted for by a reduced rate of liver and muscle glycogen breakdown (Jung et al., 2004). Endurance training increases the capacity of skeletal muscle to store glycogen (Kiens et al., 1993). The ability of trained muscles to use fat as an energy source is also improved, and this greater reliance on fat spares glycogen stores. As shown in Table 6, Moringa extract significantly elevated these carbohydrates relative to the control group $(\mathrm{P}<0.05)$. This remarkable increase of liver and muscle glycogen levels seem to be a great contributor to the increase in swimming time during training sessions (Figure 2). These results suggest that Moringa extract has the capacity to decrease or slow the utilization of carbohydrate sources; otherwise physical fatigue occurs by depletion of glycogen. This result is concordant with the earlier published reports on acute effect of leaves extract from $M$. oleifera on physical fatigue (Lamou et al., 2016).

\section{Conclusion}

In conclusion, our data suggest that Moringa oleifera extract may have beneficial effects on endurance capacity, recovery from fatigue and promoting adaptations. The possible underlying mechanisms could be mediated by the delay in the accumulation of serum lactic acid and blood urea nitrogen, increase in fat utilization and upregulation of skeletal muscle metabolic regulators. In addition, the results suggested that supplementation of Moringa extract reduced exercise-induced oxidative damage through its antioxidant potential. These results also confirm that $200 \mathrm{mg} / \mathrm{kg}$ is the optimum dose with anti fatigue activity. However, further investigations are 
necessary to elucidate the molecular mechanisms at the cellular level including the effect of bioactive constituents on the expression of fatigue responsive metabolic regulators and genes.

\section{Acknowledgement}

We would like to express our gratitude to the Physiology Lab., Department of Animal Biology and Physiology, Faculty of Science, University of Yaoundé I, and Physical Activity Biology Lab., Department of Physical Activities Biology and Sport Education, National Institute of Youth and Sports of Yaounde, Cameroon.

\section{Conflict of interest statement}

Authors declare that they have no conflict of interest.

\section{References}

Alessio, H.M., Goldfarb, A.H., 1988. Lipid peroxidation and scavenger enzymes during exercise: Adaptive response to training. J. Appl. Physiol. 64, 1333-1336.

Andreeva, I.E., Makeeva, V.F., Livanova, N.B., Petukhov, S.P., and Kurganov B.I., 2001. Studies on interaction of phosphorylase kinase from rabbit skeletal muscle with glycogen in the presence of ATP and ADP. Biochim. Biophysiol. Acta 1549, 188-196.

Barnett, A., 2006. Using recovery modalities between training sessions in elite athletes does it help? Sports Med. 36(9), 781-796.

Belviranli, M., Gökbel, H., 2006. Acute exercise induced oxidative stress and antioxidant changes. Eur. J. Genet. Med. 3(3), 126-131.

Chun, Y., Yin, Z.D., 1998. Glycogen assay for diagnosis of female genital Chlamydia trachomatis infection. J. Clin. Microbiol. 36(4), 1081-1082.

Davies, K. J., Quintanilha, A. T., Brooks, G. A., Packer, L., 1982. Free radicals and tissue damage produced by exercise. Biochem. Biophys. Res. Comm. 107, 1198-205.

Ding, J.F., Li, Y.Y., Xu, J.J., Su, X., Gao, X., Yue, FP., 2011. Study on effect of jelly fish collagen hydrolysate on anti-fatigue and anti-oxidation. Food Hydrocolloid. 25, 1350-1353.

Ellman, G. L., 1959. Tissue sulfhydryl groups. Arch. Biochem. Biophys. 82(1), 70-77.
Elokda, A. S., Nielsen, D. H., 2007. Effects of exercise training on the glutathione antioxidant system. Eur. J. Cardiovasc. Prev. Rehabil. 14(5), 630-637.

Ferrauti, A., Pluim, B.M., Busch, T., Weber, K., 2003. Blood glucose responses and incidence of hypoglycaemia in elite tennis under practice and tournament conditions. J. Sci. Med. Sport. 6, 28-39.

Foidl, N., Makkar, H.P.S., Becker, K., 2001. The potential of Moringa oleifera for agricultural and industrial uses. In: The Miracle Tree: Multiple Attributes of Moringa (Ed.: Fuglie, L. J.), Church World Service, Dakar, Senegal, pp.45-76.

Fuglie, L. J., 2001. Introduction to the multiple uses of Moringa. In: The Miracle Tree: The Multiple Attributes of Moringa. (Ed.: Fuglie, L. J.), Church World Service, Dakar, Senegal, p. 177.

Hao, G., Zhang, C., Cao, W., Hao, J., 2014. Effects of intragastric administration of five oyster components on endurance exercise performance in mice. Pharmaceut. Biol. 1, 1-6.

Huang, L. Z., Huang, B. K., Ye, Q., Qin, L. P., 2011. Bioactivity-guided fractionation for anti-fatigue property of Acanthopanax senticosus. J. Ethnopharmacol. 133, 213-219.

Jones, N. L., Havel, R. J., 1967. Metabolism of free fatty acids and chylomicron triglycerides during exercise in rats. Amer. J. Physiol. 213, 824-828.

Jung, K., Kim, I. H., Han, D., 2004. Effect of medicinal plant extracts on forced swimming capacity in mice. J. Ethnopharmacol. 93, 75-81.

Kiens, B., Éssen-Gustavsson, B., Christensen, N.J., Saltin, B., 1993. Skeletal muscle substrate utilization during submaximal exercise in man: effect of endurance training. J. Physiol. 469, 459-478.

Lamou, B., Sotoing, T. G., Hamadou, A., Abene, Houlray, J., Mey, A. M., Vernyuy, T. P., 2016. Antioxidant and antifatigue properties of the aqueous extract of Moringa oleifera in rats subjected to force swimming endurance test. Oxid. Med. Cell. Longe. Vol. 2016, Article ID 3517824, 9 pages.

Li, M., Donglian, C., Huaixin, L., Bende, T., Lihua, S., Ying, W., 2008. Anti-fatigue effects of salidroside in mice. J. Med. Coll. PLA. 23, 8893. 
Mall, T. P., Tripathi, S. C., 2017. Moringa oleifera: A miracle multipurpose potential plant in health management and climate change mitigation from Bahraich (UP) India - An overview. Int. J. Curr. Res. Biosci. Plant Biol. 4(8), 52-66.

Mattson, M. P., 2000. Neuroprotective signaling and the aging brain: take away my food and let me run. Brain Res. 886, 47-53.

Misra, H.P., Fridovich, I., 1972. Determination of the level of superoxide dismutase in whole blood. Yale University Press, New Haven. 1, 101-109.

Moylan, J.S., Reid, M.B., 2007. Oxidative stress chronic disease and muscle wasting. Muscle Nerve. 35, 411-429.

Nikinmaa, M., 1997. Oxygen and carbon dioxide transport in vertebrate erythrocytes: an evolutionary change in the role of membrane transport. J. Exp. Biol. 200(2), 369-380.

Okwari, O. O., Emerole, C. G., Dasofunjo, K., Ezugwu, H. C., Obi, J., 2014. Haematological profile of rats administered with aqueous leaf extract of Moringa oleifera following thermooxidixed palm oil diet induced toxicity. J. Pharm. Biol. Sci. 9, 41-45.

Oyeyinka, A. T., Oyeyinka, S. A., 2018. Moringa oleifera as a food fortificant: Recent trends and prospects. J. Saudi Soc. Agric. Sci. 17(2), 127136.

Peake, J., Suzuki, K., 2004. Neutrophil activation antioxidant supplements and exercise-induced oxidative stress. Ex. Immunol. Rev. 10, 129141.

Piattoly, T., 2005. L-glutamine supplementation: Effects on recovery from exercise B.S. A Thesis Submitted to the Graduate Faculty of the Louisiana State University and Agricultural and Mechanical College in partial fulfillment of the requirements for the degree of Master of Science, Department of Kinesiology, Louisiana, USA.

Prasad, V. M. P., Khanum, F., 2012. Antifatigue activity of ethanolic extract of Ocimum sanctumin rats. Res. J. Med. Plant. 6(1), 37-46.

Qi, B., Liu, L., Zhang, H., Zhou, G. X., Wang, S., Duan, X. Z., 2014. Anti-fatigue effects of proteins isolated from Panax quinquefolium. J. Ethnopharmacol. 153(2), 430-434.

Shao, J. P., 2011. Anti-fatigue effect of aqueous extract of salvia in endurance training rats' skeletal muscle. Int. J. Phys. Sci. 6(11), 26972700.

Sinha, A. K., 1972. Colorimetric assay of catalase. Anal. Biochem. 47(2), 389-394.

Suh, S. H., Paik, I. Y., Jacobs, K., 2007. Regulation of blood glucose homeostasis during prolonged exercise. Mol. Cells. 23, 272-279.

Tallec, D., 2008. Thé café: Aliments ou médicaments. La Phytothérapie Européenne. 43, 22-27.

Tan, W., Yu, K., Liu, Y., Ouyang, M., Yan, M., Luo, R., 2012. Anti-fatigue activity of polysaccharides extract from Radix Rehmanniae Preparata. Int. J. Biol. Macromol. 50, 59-62.

Terblanche, S. E., 2000. The effects of exhaustive exercise on the activity levels of catalase in various tissues of male and female rats. Cell Biol. Int. 23(11), 749-753.

Thilza, I. B., Sanni, S., Zakari, A. I., Sanni, F. S., Muhammed, T., Musa, B. J., 2010. In vitro antimicrobial activity of water extract of Moringa oleifera leaf stalk on bacteria normally implicated in eye diseases. Academia Arena. 2(6), 80-82.

Tsopanakis, C., Tsopanakis, A., 1998. Stress hormonal factors fatigue and antioxidant responses to prolonged speed driving. Pharmacol. Biochem. Behav. 60, 747-751.

Wang, J. J., Shieh, M. J., Kuo, S. L., Lee, C. L., Pan, T. M., 2006. Effect of red mold rice on antifatigue and exercise-related changes in lipid peroxidation in endurance exercise. Appl. Microbiol. Biotechnol. 70, 247-253.

Wang, Z. B., Yan, B., 2010. Gastrodia elata Blume extract ameliorates exercise-induced fatigue. Afr. J. Biotechnol. 9(36), 5978-5982.

Westerblad, H., Allen, D. G., Lannergren, J., 2002. Muscle fatigue: Lactic acid or inorganic phosphate the major cause? New Physiol. Sci. 17, 17-21.

Wilbur, K.M., Bernheim, F., and Shapiro, O.W., 1949. The thiobarbituric acid reagent as a test for the oxidation of unsaturated fatty acids by various agents. Arch. Biochem. Biophys. 24(2), 305-313.

Wu, J. L., Wu, Q. P., Huang, J. M., Chen, R., Cai, M., Tan, J. B., 2007. Effects of L-malate on physical stamina and activities of enzymes related to the malate aspartate shuttle in liver of mice. Physiol. Res. 56, 213-220.

Yi, F., 2000. The experimental study for 
Gynostemma pentaphyllum with sport endurance? J. Chengdu Physical Educ. Inst. 26(2), 63-65.

You, L. J., Zhao, M. M., Regenstein, J. M., Ren, J.
Y., 2011. In vitro antioxidant activity and in vivo anti-fatigue effect of loach (Misgurnus anguillicaudatus) peptides prepared by papain digestion. Food Chem. 124(1), 188-194.

\section{How to cite this article:}

Bonoy Lamou1, 2*, Ebal Minye Edmond2, Mbouh Samuel2, Hamadou André2 and Tan Vernyuy Paul1, 2019. Adaptogenic effects of the leaves aqueous extract of Moringa oleifera in rats. Int. J. Curr. Res. Biosci. Plant Biol. 6(9), 33-43. doi: https://doi.org/10.20546/ijcrbp.2019.609.005 